\title{
Quasi-mysticism in Beckett's Major Plays
}

\author{
Bahee Hadaegh \\ Shiraz University, Iran \\ Email: bhadaegh@rose.shirazu.ac.ir
}

\begin{abstract}
It positively evaluates the particular approach of the late modern tragic characters through the lens of the author's own cultural background, bringing some evidence from Persian mystic (Sufi) poetry which reflects the concept of rejoicing suffering, self-annihilation, and finally self-realization. This way, the so-called absurdity labeled for Beckett's plays can positively be replaced by a meaningful term which might be called "mystic nothingness". The study reveals that as tragic characters readily get involved in the substratum of suffering from modern times, they increasingly manifest a more comprehensive degree of self-realization.
\end{abstract}

\section{Index Terms — self-realization, mysticism, tragedy, Beckett's absurd plays, annihilation}

"Old endgame lost of old, play and lose and have done with losing."

\section{(Endgame 51)}

Given the thematic and conceptual affinity between the absurd drama of Beckett and basic mystical trend of annihilation and rebirth, the present paper tries to demonstrate a new dimension of the quest for the authentic self in its recurring tradition. The critique focuses selectively on the two major plays of Beckett namely Waiting for Godot, and Endgame. Through locating a new trajectory of inquiry, the study tries to demonstrate that the characters' intentional involvement in a kind of negative and cyclical attempt towards self-realization is positive and fruitful in the light of mystical notion of annihilating action. As the interminable paralysis of the ego recurrently breaks temporal and spatial bondages through complete ignorance, cyclical movement of everydayness, or habitual talk, it is rarely shattered by the interrupting forces of the outside reality and thus the achievement of the wished-for spiritual peace is more likely.

Unlike the commonly held view of the search for the longed-for identity in the absurd plays as nihilistic, it is possible to see them as positively meaningful in their negative, non-active aspect. The characters are consciously shrinking away from the outside world to a protective reduced atrophied lessness which is manifest in their unhousedness, broken utterance, and defective physical features. The atrophying attempts of such characters delineate a movement towards the centre, demonstrating the ongoing transmutation of the conscious ego into the spiritual world of the unconscious. Beckett insists on encouraging performances which limit the external physical techniques and work toward inward psychological centres (Kalb, 1989, p. 22).

In the beginning scene of Waiting for Godot, Vladimir demonstrates the prelude of a new approach in his resumed struggle: "All my life I've tried to put it from me, saying, Vladimir, be reasonable, you haven't yet tried everything. And I resumed the struggle" (370). This inactive and reductive strategy is prevalent in the bare stage setting of a country road with a naked tree and a setting sun. Parallel with the objective reduction, the play reveals subjective selfdiminishment manifest in Estragon's symbolic attempt to take off his shoes. Vladimir's response intensifies the importance of such a reduction when he emphasizes that "boots must be taken off every day. I'm tired telling you that. Why don't you listen to me?"(371). The fact that Vladimir in the same way takes off his hat and peers into it recurrently shows his spiritual discomfort. Given the symbolic role of the hat, which represents thought in Lucky's case, Vladimir's discomfort in taking it off and recurrently peering into it can likewise imply his struggle to get rid of the rational faculty. Vladimir complains about the impropriety of his hat and is doubtful about the suitability of Lucky's hat as well: "Then I can keep it. Mine irked me. (Pause.) How shall I say? (Pause.) It itched me". (He takes off Lucky's hat, peers into it, shakes it, knocks on the crown, puts it on again) (390).

Estragon's problem with his boots suggests the inefficacy of a mobile quest. Beckett's inactive style is manifest from the very beginning in his scenic directions. For instance, evaluating Beckett's plays, Cohn (1962) refers to his scenic direction for Eleutheria and notes that Beckett created not so much an action as a space, often empty. He continues to say that "Beckett's intention was to harmonize stage setting with soul setting" (19).

The shrinking course of development is visible in Beckett's three major plays and is thematically summarized in Vladimir's idea when he says: "There's man all over for you, blaming on his boots the faults of his feet" (372). Here, Vladimir prescribes the complete detachment or atrophying approach for the spiritual malady of lost identity for which neither Estragon's boots nor Vladimir's hat could offer a treatment. In other words, both practicality and rationality seem to be unreliable in helping the individuals realize the authentic self.

This kind of atrophying approach is very similar to the idea of self-annihilation in Persian mysticism which asserts that being bodiless leads to the manifestation of an authentic self. This kind of relationship which is the basic trend of Persian Sufism is emphasized by Rumi (2001): "Headless, footless, indeed, without retinue I lead, / In my own sweet land, sweetness to myself feed" (101). 
In the light of Persian Sufi philosophy, the inaction of Beckett's characters can be categorized by a stage-bound procedure which is reminiscent of the Sufi stages of the soul explained in Attar's The Conference of the Birds. ${ }^{1}$ The process begins with a conscious quest or 'Talab' which basically demands a conscious search for a higher self. In this stage, the characters' involvement is so that they completely submit themselves to the quest and detach themselves from the outward environment. This kind of detachment is called 'Faqr'. The detachment symbolically appears in different manifestations like waiting, solitude, self-imprisonment, or self-burial. After undertaking several painstaking efforts like heedless melancholic persistence that is known as 'Eshgh', self-protection or 'Moraghebeh' appears that includes self-forgetfulness, dumbness, or deafness leading to uncertainty, dejection, suffering and bewilderment or 'Tahayyor'. The characters ultimately reach the final stage of self- annihilation or 'Fanā' that simultaneously implies the rebirth or 'Baghā' of the human essence (Nott, 1954, pp. 124-8).

In Waiting for Godot, the rudimentary means for enacting is reflected in the names of the tramps reduced to Gogo and Didi. Considering the tramps' reduced names which reflect the attributes they stand for as defective motion and deed (Gogo-Didi), it can be inferred that the reduction is meant to reveal the essence. Beckett's reduced world can be considered as stripped to essentials. Such a collapse unbinds the essence through offering freedom. This paradox "negate[s] every possibility of movement and rationality, the more the creatures are immobilized and dehumanized, the more freedom they seem to gain to extricate themselves" (Federman, 1979, p. 105). In a 1992 interview, Asmus (1982) refers to a kind of freezing movement in directing Godot at the Schiller Theatre in Berlin in 1974. He also refers to balletic movement of the actors which express Beckett's belief in a "blocking that had a meaning" (344). Within this context, the freezing collapse of the action is meaningful and positive.

The characters' recurrent forgetfulness similarly delineates the diminished power of consciousness which is reinforced with their continuous chat as a paralyzing agent. The quest of the tramps is basically accomplished by reducing action to non-action as expressed by Vladimir: "Don't let's do anything. It's safer" (380). They prefer not to act as they are afraid any action might interrupt the constancy of the process of the quest. Vladimir states it obviously when he says: "Let's wait till we know exactly how we stand" (381). However, after Vladimir's vague supplication, Godot's answer displays how they should act. It is as if Vladimir already knows what he should do and automatically is doing what he has been asked. He is waiting as Godot implied in his answer to his prayer. "That he'd see," "That he couldn't promise anything" and finally "That he'd have to think it over," (382) — all of which demand waiting. Estragon's asking if they are tied to Godot ascertains that Vladimir is exactly doing what Godot expects them to do, that is waiting and doing nothing: "To Godot? Tied to Godot! What an idea!"'(385).

Pozzo's and Lucky's entrance into the scene following Vladimir's reveals an unconscious link between them and Godot. That Pozzo and Lucky are tied together is a concrete illustration of the hidden link existing between the tramps and Godot. In his bondage to Pozzo, Lucky carries a huge burden of luggage which makes him uncomfortable. When Pozzo reveals the secret of this self-imposed suffering, it appears that through this kind of shrinking Lucky can stay tied to Pozzo as a way of protection against the endangering threats of the fair where he is going to be sold: "He imagines that when I see how well he carries I'll be tempted to keep him on in that capacity.....He imagines that when I see him indefatigable I'll regret my decision" (Pozzo 399).

Considering the role of suffering as a reductive element and its ability in paralyzing the conscious ego and its transmutation to the spiritual world, Lucky persists in carrying heavy burdens and suffering severely. The fact that Lucky finally bleeds symbolically indicates a severe self-renunciation which leads to a moment of epiphany manifest in his monologue. Nearly paralyzed after his monologue, Lucky "recovers his senses gradually at the feel of his bag" (416). It is not until the second act where Lucky's anticipation proves to be true. Here, Pozzo enters while he is blind and needs Lucky as his master this time. The rope is now shorter as Pozzo can follow Lucky easily. Lucky's nearness to Pozzo signifies that he is gradually approximating emancipation and spiritual mastery. Such a symbolic demonstration shows that all of Lucky's self-mortification has been fruitful, taking him from slavery to mastery. On the other hand, given the uncertain identity of Pozzo, who is recurrently considered to be Godot, it can be proposed that Lucky has already approximated the longed-for transcendence or the unified whole which is incarnated in the God-figure of Godot through being tied to him and persisting in reductive suffering.

Following Lucky's reductive efforts, Vladimir confidently remarks that "We were beginning to weaken. Now we're sure to see the evening out" (454). Here, Vladimir implies the rewarding nature of Lucky's reductive attempts. He thus reveals his satisfaction immediately: "We are no longer alone, waiting for the night, waiting for Godot, waiting for ... waiting. All evening we have struggled, unassisted. Now it's over. It's already to-morrow" (455). Vladimir finds that waiting keeps him tied to Godot which is itself the attainment of the looked-for spiritual rebirth. Waiting can be considered as a diminishing strategy manifest in the allegory of Lucky's endurance. The Pozzo-Lucky binary of attachment, in a similar vein, is the prototype of the play's dominant motif of detachment and illumination.

This kind of recognition is symbolically demonstrated in the elaborate exchange of the hat scene, with Lucky's hat fitting both Vladimir and Estragon. Vladimir is now more certainly doing what Lucky has been demonstrating in presenting a suffering Christ-figure. He suggests role-playing to Lucky, which connotes his preoccupation with this promising approach: "We could play at Pozzo and Lucky... I'll do Lucky, you do Pozzo" (449). He imitates Lucky

7-Seven stages of self-perfection also known as seven valleys of the quest. For a complete introduction to Sufi stages see Charles Stanley Nott's translation of Attar's The Conference of the Birds. 
sagging under the weight of his baggage. The role playing is positively followed by the second coming of Pozzo and Lucky whom the tramps see as Godot's arrival. The triumphant shout of Vladimir echoes phonemes which reflect the seekers' sense of self-unification. Taking Pozzo as Godot, Vladimir shouts: "It's Godot! At last! Gogo! ” (450). The nearby phonemes suggest that Gogo is Pozzo who is considered to be Godot. Pozzo is seen continually playing with his names: "Godet ... Godot ... Godin ..." (19). Equally, the two tramps are not sure about the name of Pozzo:

ESTRAGON. His name is Godot?

VLADIMIR. I think so.

ESTRAGON. Fancy that .... (14)

Godot's present absence is once more revealed when Estragon asks:

ESTRAGON. Is that him?

VLADIMIR. Who?

ESTRAGON. (trying to remember the name) ... Er

VLADIMIR. Godot?

ESTRAGON. Yes.

POZZO. Pesent myself: Pozzo

VLADIMIR. (to Estragon).Not at all!

ESTRAGON. He said Godot.

VLADIMIR. Not at all. (15)

In other words, Gogo, Didi, Lucky and Pozzo who are either visibly or invisibly tied together, in being so completely alike, imply that they are the fragmented aspects of one unified whole. Lamont (1957) also studies the similar sound of the names in this play. He states that "even their names sound like the distorted double echo of a single name uttered in the void. Reverberated Godot might become either Gogo or Didi, a child-like nickname for God or Dieu" (199). Such a unity which emanates from visible or invisible attachment ironically means a detaching withdrawal from the world of matter and transmutation of the ego to the spiritual world of unconscious and achieving the Godot of identity. Such a fusion is reminiscent of the Sufi story in Attar's Conference of Birds when the thirty birds, looking for the absent kingbird named 'Thirtybird', after "waiting long enough" (1557) and undertaking a number of self-reductive stages and suffering, find that they are 'Thirtybird' themselves. The quest of the thirty searching birds takes them through seven valleys of the self-annihilating quest in the first of which they withdraw from the world. They undergo many trials as they try to free themselves from all their precious belongings. Once successful and filled with longing, they ask for wine to dull the effects of dogma, belief, and unbelief on their lives, symbolizing the complete forgetfulness of worldly attachment. They give up reason and pass through seven valleys of 'forgetfulness', 'love', 'detachment', 'unity', 'bewilderment', 'manifestation', and 'annihilation'.

Assailed by suffering and dejection, they feel that they know nothing. They are not even aware of themselves. The thirty birds finally reach the abode of the 'Thirthybird' (Phoenix). But there is no 'Thirthybird' (Phoenix) anywhere to see. Thirthybird's chamberlain keeps them waiting for him long enough for the birds to figure out that being thirty birds, they are 'Thirthybird' themselves. It is the thirty birds themselves who are lost in the valleys of detachment, attaching themselves to the sea of the king's existence through long period of waiting. The allegory of thirty searching birds looking for the absent king-bird phoenix named 'Thirtybird' (Simurgh) throws light on the absence of Godot who is already present through Gogo, Didi and Pozzo in Beckett's play.

It is through the help of illusion that Beckett's tramps are able to ascend the conscious ego and reach a greater self: "We're in no danger of thinking any more ... Thinking is not the worst ... What is terrible is to have thought" (64). Waiting "can have as consequence a consummation that provides a clear understanding of the self and its relation to the situation- a state of being-free from the morbid transition of matter" (Ghosh, 2004, p.308). Even toward the end of the play when Vladimir is about to realize he has been dreaming and must wake up to face reality, the appearance of Godot's messenger plunges the tramps back into the inactive world of illusion. Interpreting the notion of waiting under Hindu philosophy, Ghosh (2004) sees waiting as a proof of Godot whom he would think as the true self. He adds that, "waiting is a striving towards attainment of identification with the ultimate (Godot)" (313).

Immediately after the boy leaves the tramps, in a determined gesture Estragon finally throws away his boots and decides to continue his mission bare-footed as the suffering figure of Christ. Bare-footed like the Christ, he is determined to suffer and continue his waiting: "Then all we have to do is to wait on here" (426). Lucky's conative persistence in enduring suffering proves to be the prototype of the quest for self-realization. This kind of persistence is demonstrated concretely in the Christ-like figure of Lucky which invigorates an enduring process of reduction. Vladimir's conviction - "you're right, we're inexhaustible" (435) — as a result, is similar to the way Pozzo describes Lucky's indefatigable persistence under the heavy load of his luggage. Referring to the positive function of waiting Lamont even argues that "in Waiting for Godot, Vladimir and Estragon may not stray far from their place of waiting, yet they come to realize that patient expectation of something or someone has meaning in itself, that it represents in fact the enduring hope of mankind" (200).

Productive endurance once more comes into view when Vladimir's decisive fortitude leads to another moment of manifestation: "Wait ...we embraced...we were happy...happy...what do we do now that we're happy...go on waiting...waiting...let me think...it's coming...go on waiting...now that we're happy...let me see...ah! The tree!" (439) 
Vladimir's exuberant waiting as persistence is followed by his sudden illumination symbolized in sprouting of the leaves. The relationship notifies how productive the dwindling suffering of endurance is. The final promising signal for the rebirth occurs when the detaching binding of Lucky and Pozzo is in its most atrophied condition as they have been dumb and blind. They are falling on the ground helplessly exhausted under the huge burden of the sand bag. Here, Pozzo reveals the secret of the quest: "We wait till we can get up. Then we go on. On!"'(469) It is after such a severe loss of practicality emblematic of the diminishing waiting of the tramps that the boy messenger reappears and promises Godot's coming. The dominant motif of the reduction-rebirth is also manifest in the whole structure of the play as the two scenic directions of silence and pause are immediately followed by a fresh start after stillness.

In Waiting for Godot, waiting has repressed all kinds of action and in so doing the regressive process has intensified the death-wish which is manifest in the tramps' gradual reference to suicide. The idea of hanging is not put in practice until late at the end of the second act where they each take an end of the cord and pull. They have progressively found that the more they shrink, the more certain the coming of Godot will be. However, the constant deferral of suicide, even on the verge of doing it, demonstrates the tramps' particular strategy -- that is, waiting and the ongoing renunciation of life. This serves as a clearing of space so that there will be room for the possibility of transfiguring grace which, as Vladimir says, suddenly leads to the manifestation of a higher self. "It'll fall all of a sudden ... (447). The process is parallel to the steady series of losses for Lucky and Pozzo who lose their mobility, sight and speech in the second act. It is followed by the second coming of the boy messenger, symbolizing a rebirth. In other words, the death-wish is the extension of suppressive nature of waiting which the tramps knowingly adhere to. Vladimir represents the ongoing process of loss this way: "We wait. We are bored. No, don't protest, we are bored to death, there's no denying it. Good. A diversion comes along and what do we do? We let it go to waste. Come, let's go to work! In an instant all will vanish and we'll be alone once more, in the midst of nothingness!" (459)

The symbolic disclosure of this kind of progressive regression which is meant to end in the manifestation of authentic self emerges in the recurrent juxtaposition of beginning and end in addition to womb and grave counterpoint images. Earlier in the play, Vladimir's bright idea has been to repent, which leads to Estragon's suggestion that they have been doing it from the moment they were born. Here, Estragon sees the secret of being in not-being. The setting itself pinpoints the mystic binary notion of renunciation and rebirth with its vast horizon against one vertical tree and four characters falling down while looking up at the sky. The scenery remarkably reinforces the possibility of ascent through falling.

Lacan's theory of death and desire proposes that "life and death are compounded in a polar relation at the very heart of phenomena related to life" (qtd. in Kim, 2003, pp.102-4). Lacan signifies that suicide cannot end in the manifestation of the true being as it transgresses the natural law, since being born is not a matter of choice. Thus, the reason why the tramps once more defer hanging themselves despite their final attempt towards physical loss is that the manifestation of the authentic self depends on the recurrent process of loss, not the sudden termination of life. In other words, the practical approach of committing suicide in the second act is the suggestive demonstration of the maturing process of waiting which symbolizes the continuous process of loss. Moreover, it is reminiscent of the ego's conscious attempt to connect to the spiritual world symbolized in Godot's figure. The power of waiting is thus making relation between human beings and the unified whole. In fact, "waiting inveterate anticipation ascertains and appends value to reality where the totality of reality is realized in the maturity of the partnership" (Ghosh, 2004, p. 317).

In a similar vein, Sufis recurrently suspend their egos in a state of non-being, annihilation or 'Fana' which simultaneously leads them to a 'permanent existence' or 'Baqa'. It is through this perpetual stripping of one's existence in time that the Sufi returns to the pre-existence or the essence. Describing Sufi stages of the quest, Al-Tirmadhi (2003) asserts that the turning point of the quester is when he is able to strip himself from all that rises from the ego. He adds that the Sufi cannot choose to terminate his unsatisfactory existence through physical death since to choose presupposes the involvement of the ego (104). Therefore, Sufis only keep stripping the ego which automatically, as they believe, leads to the transference of condition bringing them to annihilation and its simultaneous perpetual existence.

In waiting for Godot, Estragon concludes that "nothing is certain" and among all the approaches the tramps have already tried, what is left certain is waiting, which they keep on doing. The general cyclical pattern of the play reinforces the idea as through repetition the characters renew their waiting as the only means of connection to the world of meaning. Specifically, the cyclical appearance of the boy messenger and the master-slave duo intensifies the motif of presence through waiting. It is what Robbe Grillett (1963) calls "metaphysic of presence" (65).

The fact that Beckett reduces the tramps to a limited state of movement doing very limited actions indicates how they have atrophied themselves in their longing to visit Godot. In fact, the active inaction of the tramps demonstrated in Waiting for Godot is a nullifying-filling process which is purposefully cyclical. The continuous reductive attempts of the tramps to reach the minimum threshold of being through waiting makes the questers attain a sense of union with the world of ultimate presence.

Along with waiting, the process of transmutation is also manifest in the genius of the characters for forgetfulness. The characters' forgetting names leads to moments of epiphany. The lyrical cross-talk of Vladimir and Estragon is directed toward forgetting reality. Lucky's dance of the net in a similar vein, represents another attempt through which the characters try to transmute the ego to the spiritual world of unconscious. 
The mystic's annihilation of the conscious ego is similar to the characters' forgetfulness in Waiting for Godot. In the process of annihilation, mystics do not mention their names even when addressing themselves. This practice leads to mystical experiences of seeing the spiritual master which can be interpreted as seeing the greater self. Annihilation of the mundane self makes room for apprehension of the alert master/ transcendent self.

The play of being and non-being recurs in Endgame where the cyclical process of annihilation and rebirth is more manifest. More reduced than Waiting for Godot, the world is utterly atrophied and the motif of annihilation is implied more severely in the way the characters are obsessed with the most possible degree of self-reduction: "I can no longer endure my presence" (21). In other words, ubiquitous reduction is the dominant motif of the play: "One day you'll be blind, like me. . . Infinite emptiness will be all around you, all the resurrected dead of all the ages wouldn't fill it, and there you'll be like a little bit of grit in the middle of the steppe"(Endgame 28). In a suggestive way, all the names of the play mean 'nail' in different languages. Even Hamm, which is very similar to the Latin word Hamus, means 'hook'. Reflecting the idea of annihilation, all of these symbolic names suggest that the characters are similar to nails which should be hammered. Compared to the semi-detached scene of the barren country road of Waiting for Godot, the detachment is more severe in the prison-like confinement of the room in Endgame. The fact that Clov explicitly praises his ultimate self-confinement once more asserts the notion of perfection in reduction and loss. "I'll go now to my kitchen, ten feet by ten feet, and wait for him to whistle me. Nice dimension, nice proportions" (12). Such an emphatic focus is reminiscent of the recurrent motif of number ten in Beckett's Quad which reflects Pythagoras's idea of perfection symbolized in this number.

The scattered images of womb and tomb in Waiting for Godot develop to a more concrete play of death and life in Endgame through a severe self-reduction along with passive waiting. The characters are demonstrated in their struggle to limit their physical existence in order to live. The ubiquitous theme of reduction suggests that as humans atrophy themselves towards a complete annihilation of the self, a new life appears. They recurrently struggle to release themselves from the bondages of life and reach the free soul through atrophying themselves. The master figure of reduction is emphasized by the protagonist at the start. He appears with a face covered with a white, bloody handkerchief symbolically implying that he is corpse. The fact that the play's dialogue opens with the word 'finish' and ends with 'remain' can also be suggestive of the mystical dominant theme of annihilation and rebirth. In other words, it can be inferred that it is through finishing that you can remain. In Sufi tradition, likewise, reaching the unified whole is only possible through removing the barrier of physicality. Rumi (2001) refers to this mystical trend in Diwan e Shams:

Shams-e Tabriz, if you show not your face now My earthly corpse, by God, I shall surely disown.

Between my beloved and I this is the only veil It is time to unveil and disrobe the light that brightly shone. (114)

While Waiting for Godot implies the motif of annihilation and rebirth through symbolic images of suffering, reduction, endurance and detachment followed by images of hope, Endgame shows development towards a cyclical, ubiquitous reduction leading to rebirth, not unlike the reversal of Job's misfortunes: "Old endgame lost of old, play and lose and have done with losing"(51). Endgame's conscious approach of loss is revealed in how the central character, Hamm intentionally announces "me to play" for a game that is already lost. Like waiting, the recurrent play of loss acts as the central paralyzing agent of the play. Hamm's fanciful mind which is manifest in composing brief passages of a tale every day throws light to the dominant motif of evasion from the conscious ego to the ascending world of the unconscious. He demonstrates the overall perspective in being completely motionless and blind with a suggestive name as abbreviated form of Hamlet connoting melancholy and irrationality. From the very beginning, the ironic direct relationship of loss and gain is manifest in Hamm's character. Despite his sheer immobility, lack of sight and memory, Hamm is the master king of the play centralizing himself physically and influentially. His recurrent emphasis on the words like 'end' or 'suffer' indicates how obsessed he is with the idea of reduction. In a parallel way, Clov demonstrates his idea about suffering as a liberating factor: "I say to myself sometimes, Clov, you must learn to suffer better than that if you want them to weary of punishing you -- one day" (51). Mobility is explicitly rejected when Hamm addresses Clov as condemned to pollute the air when he moves a little. In a more negative action, Hamm starts the day by going to bed, signifying the grave or death. More violently he insists that all the signs of life should be destroyed, as when he urges Clov to kill the fly.

Mystically, through cyclical reduction of the self, Hamm is already saving himself from the endangering material life. The way Hamm tries to unpeople the earth is a symbolic attempt to lessen existence and thereby get nearer to the source of being in his non-being. Ruby Cohn (1962) refers to this matter and asserts: "to in-exist is divine" (156). She adds that through not-being, individuals can gain relief. More intensely than the tramps in Waiting for Godot, Hamm tries to falter towards the end. The fact that everything in Endgame is being destroyed progressively while the end is continuously deferred indicates the maturing nature of waiting. Cohn finally concludes that "this faltering is not energetic and life giving, it is towards taking life" (156). Here, faltering is a kind of annihilation done through creating more opportunities for loss and demolition. While in Waiting for Godot, the sudden idea of being tied to Godot [waiting] converts the absurd existence to a meaningful, fruitful mission through reaffirming promise of the child messenger, the recurrent faltering of the end in Endgame leads to the appearance of a manifest rebirth. In other words, while the child messenger promises that Godot, the longed for identity, will come tomorrow, out of the recurrent faltering of Hamm, a manifest rebirth occurs in the concrete image of a child born among the ashes of non-existence. 
The appearance of the little boy (a potential procreator as Clov calls him) who suggests a resurrected life is immediately followed by Hamm's sudden illumination: "It's the end, Clov, we've come to the end, I don't need you any more" (49). In an action which is reminiscent of the Buddha, the little boy contemplates his navel, symbolizing meaningful nothingness. His contemplating presence convinces Hamm about the appearance of a new life. The fact that Hamm does not need Clov any more indicates Hamm's ability to witness his own longed-for spiritual stasis and does not need anybody else to validate his existence. If we consider the appearance of the little boy as Hamm's spiritual self, we can conclude that Hamm is finally present to his being and no longer needs Clov to witness his presence.

The fact that in the French original version of the play, the little boy is called "potential procreator" throws light on the mystic philosophy of the attainment of the non-being state before creation. Passing through a long time of conscious deprivation and loss, the individuals can finally reach the primal state of being, the Non-existence which means the absolute annihilation of the self to the unified whole. Despite the sudden self-recognition, the reason why Hamm still insists on continuing to play the game of loss indicates the persistent desire of the character to keep the experience of loss, which means the recurrent loss of the ego. Stopping the cyclical process of loss makes the questers return to the conscious ego they have been already looking for. Hamm's frequent refrain, "something is taking its course", can be considered as the emergence of a new life.

Instead of committing suicide, Beckett's characters cling to the recurrent play of loss and gain. This can be justified under the light of the mystical notion of self and nothing. Buri (1997) argues:

The mystics speak of being dead not in the biological sense as an irreversible occurrence but in a figurative sense as an extraordinary experience from which they again return into conscious world of objects. Yet, here again, the experienced nothing becomes something. (189)

He adds that "here, this nothing can perhaps even open us for transcendence" (189). Mystically, Buri relates this phase of nothingness to Nirvana in Buddhism and says that this absolute nothing or the not-self or the sudden enlightenment happens after numerous rebirths "in the experience of becoming empty" (196). Finally, he concludes that "I would claim that the true self is creation out of nothing" (203).

Endgame is "certainly a play about loss" as McDonald (2006) observes (51). From the very beginning the greatest transgression is considered to be reproduction and its source is confined to rubbish bins. The world they live is demonstrated in the most depleted and belated condition. The landscape is desolate and what is left outside is 'all corpse' on the verge of expiration and lifelessness. Inside the room, there is a picture facing the wall representing a perfect withdrawal. The characters confess that they don't mean anything as Hamm says: 'We are not beginning to ... to ... mean something? Clov: Mean something? You are I, mean something! Ah that is a good one!'(27) Such a lack of desire reflects the complete expelling of the ego which connects it to the spiritual world of meaning.

While in Waiting for Godot relative relief appears in the idea of being constantly tied to Godot, implying reduction and partial detachment from any action, Endgame exhibits a conscious process of loss and the incessant active inaction to take everything to an end. Referring to this fact, Metman (1960) remarks that in Endgame Hamm "turns the process of dying into an act of dying" (134). The characters' progressive obsession with recurrent deprivation and loss is manifest in Cohn's evaluation of Beckett's three major dramas: “The tramps keep waiting, Hamm keeps finishing, and here [Act Sans Parole], the clown leans through movement to reflect, and through reflection to stop moving" (156). Hamm's attempt to keep finishing reflects the mystic endeavor of losing the ego and its gradual transmutation to the spiritual world.

The very selection of endgame for the motif of loss is significantly similar to the motif of the game loser in Sufism. In Amorous gamble the author sees mystic gambling as one of the basic teachings of Islamic mysticism through which the gambler loses continually in his way to reach the longed-for unified whole. (Soroush, 2000, p.14). Such a game of loss is praised in Sufi poem of Rumi (2001): 'Happy the gambler who lost what he gained, / Nothing left for him, but a passion to lose again.' (Divan e Shams 429. 1085)

The course of progression from Waiting for Godot to Endgame is revealed through the characters' process of continual loss which leads to the appearance of the quintessential self in the image of the child-God. In fact, the latent emergence of the new birth symbolized in the sprouting of the leaves and the boy messenger in Waiting for Godot, is manifest in explicit image of the little boy in Endgame which according to Metman "may be regarded as an image of the self'(25). The sprouting tree in Waiting for Godot reflects Beckett's idea: "Man is ... a tree whose stem and leafage are an expression of an inward sap" $(1931,25)$. This idea sheds light to the growing illumination of the inward essence. Such a growing illumination bears fruit in the image of a new life in a barren world of Endgame.

Metman's idea about the progressive course of development in Waiting for Godot and Endgame offers the possibility to interpret these plays in the light of Sufism. She writes that the ultimate inner liberation is a prelude to the emergence of a new birth in Endgame. Such an explicit manifestation is belated in Waiting for Godot as inner release is continually interrupted. The complete transmutation of the conscious ego to unconscious world is revealed in Hamm's confession: "I was never there, Clov! ...I was never there ...Absent, always. It all happened without me" (47). Here, Hamm's absence delineates the perfect dissolution of his ego which has gained through continual physical deprivation and increasing loss.

The idea is confirmed when Hamm's final enduring loss is followed by his erect and dignified posture of sitting on the chair until the fall of the curtain. The fact that the board is finally empty, no bicycle wheels, no coffin, no sugar- 
plums-pain-killer, no pap, no tide, navigator or rug implies how Hamm has been successful in the play of loss. It recalls us of the second act of Waiting for Godot where Pozzo's belonging are lost. As Robinson (1969) asserts: "In this game: to win is to lose". He adds that:

...Until near the end Hamm succeeds. Everything living like the rat and the flea is quickly exterminated, one of his pawns, Nell appears to have died and each successive end adds another grain to the heap. When the child appears in the midst of destruction, Clov demands the gaff, intending to go out and kill the child, but now that his fear is confirmed Hamm is curiously possessed and tranquil. The child's appearance seems a miracle, a birth from nothing that cannot be exterminated like the rat in Clov's chicken. (264)

He also signifies that a part has been omitted from the play's English version when the child is referred to as a Christ figure. Still in earlier recollection of the play Beckett includes this sentence: "Moses gazing at the Promised Land: "il regarde la maison sans doute, avec les yeux de moie mourant" (qtd. in Robinson, 1969, p. 264). More importantly, he remarks that "when Nell appears to die there is no grief" (269). Such tranquility is parallel to the feeling after the appearance of the little boy. Despite Clov's intention to go and kill the child with the gaff, Hamm is surprisingly seen "possessed and tranquil" (264). The tranquility gained after the birth of an existence which cannot be exterminated signifies the symbolic emergence of the authentic self after the annihilation of the ego. Likewise, the stage setting itself is set to connote the sudden emergence of some fruitful result. "The stillness of the sea and the barren earth" according to Worth "suggest the hushed expectancy of a universe waiting for creation" (190). The fact that Hamm asks Clov to see if there is any probable change reveals his expectation for something new to happen out of his self-made deprivation:

HAMM. Have you looked?

CLOV. Yes

HAMM. Well?

CLOV. Zero.

HAMM. It'd need to rain. (13)

Hamm is wondering if there is greenery there beyond the hill, invoking Flora, Pomona and Ceres. In a similar vein, Hamm has his own dreams of Flora, and Ceres which bring the idea of sun, rain, and sea connoting to the manifestation of life.

The motif of annihilation and rebirth which obviously manifests itself in Hamm's final victory after his continual loss is reminiscent of the Sufi story of the king and the handmaiden in the first book of Rumi's Mathnavi. Rumi (1898) explicitly maintains that the imposed impurities of the self are removed after undertaking continual loss. In other words, it is only through the continual abolishment of the ego that the authentic self can be retrieved. At the end of the story, Rumi concludes that:

Such a harsh treatment and rough process has a meaning...

It is so that the dross and muck from the silver is leaving.

The good... and also the bad are tested in such a way that

Gold is brought to boil and scum rises to the top of the vat (I.17)

The fact that Hamm restarts the game of loss even after the symbolic appearance of the little boy can be considered to be a redefinition of the mystic notion of being which naturally needs to be annihilated in order to be. Sartre's idea concerning the relation between being and not-being is a proper interpretation of Hamm's conscious endeavor towards not-being. He argues:

Consciousness, [self consciousness] therefore, is the imposing of a negative on a positive - a process of "neantisation." It follows that the cosmos is a dual character: all that massively exists (L'etre" or "L'en-soi") is positive, while consciousness, which organizes that which exists, is negative ("Le neant," or "le pour-soi"). Logically therefore, the pour-soi (the negation which is consciousness) must lie outside all being; only that "which is not" is able to understand that which is. The pour-soi is not Being; the pour-soi is its own Not-Being. (Sartre, 1953, p. 59)

After continual divestiture, Hamm is now completely beyond the knowledge of being. He doesn't risk turning back to his ego which is a meaningless being. Robinson even affirms that: "they [the characters] cannot endure to start again now that is almost "beyond knowing" (268). Now that Hamm is symbolically reunited to the self that exists outside time in the timeless void, he tries to keep this union through keeping that timelessness obtained through continual process of loss. Like Keats' frozen picture of the lovers on the Grecian Urn, Hamm is trying to freeze the emergence of the reborn self through the repetition of the process which created it. In Proust, Beckett himself refers to habit and repetition as "the agent of security" (21). In a more suggestive way, Clov's seeking refuge in his kitchen reinforces the idea of protecting habit. "Habit is compared to a "cook [...] who knows what has to be done, and will slave all day and all night rather than tolerate any redundant activity in the kitchen" (Proust 20). Therefore, Clov's retirement to Hamm and his kitchen reveals how he feels secure in such repetitious behaviors. At the end of the play, Clov justifies his desire to remain inside: "But I feel too old, and too far, to form new habits" (1959). He feels secure through a regular pace of losing the ego and constant deprivation. In other words, it is through conscious clinging to losing and deprivation that both Hamm and Clov find security.

Endgame's central motif of the quest for the authentic self is once more revealed in Hamm's symbolic posture in the attainment of the womb-like condition. The behavior remarkably suggests the possibility of birth passing through the atrophied stage of the embryonic existence. The round womb-like symbolic posture of Hamm within the cyclical 
closure of the overall pattern of the play is reminiscent of Jung's Mandala. Focusing the centering of personality, Jung sees individuals facing a cycle as symbolic protection of their wholeness by their repetitious reversion to the centre and producing walls around themselves. In Endgame, Hamm insists on being right in the centre but repeatedly displaces himself. In Jungian terms, his wholeness is insecure. In Proust, Beckett himself refers to the paralyzing power of habit through which the attention is more focused on the inner world, leading thereby to the protection of the essential faculty that is human essence. He says: "Habit paralyses our attention, drugs those handmaidens of perception whose cooperation is not absolutely essential (8-9). As reflected in Proust, habit thus looks behind the surface of the ego, behind voluntary to involuntary memory.

Nearly the same aspect is revealed in Doll's designation of the ritual in Endgame as psychic rebirth. She refers to Jung's theory of rituals functioning through creating a kind of insight to let the human be. Here, the paralysis of perception recalls the idea of 'deprivation and death' in Sufism. According to Attar (1999) 'the essence is forgetfulness, dumbness, and distraction. Humans at first experience humiliation and overthrow; but when he emerges from this state he will understand it as creation" (p. vii).

In fact, it is through repetition that one can exhaust the vital energy and simulate death in life. The recurrent game of loss in Waiting for Godot and Endgame, in a similar vein, represents the characters' continuous struggle to reach an infinite void in Beckett's dramas. It can be inferred that basically the notion of the self as infinite void is reminiscent of the seemingly negative mystic notions of the void either in Nirvana of Buddhism or annihilation of Sufism.

The way Hamm recurrently switches to ritualistic story-telling is in the same way along with losing his ego and reaching the infinite void of the self. The maddening repletion of certain words or recurrent story telling creates three important moments in Beckett's characters, as Doll observes:

The first moment is Regression ... the second key moment in the rite of story telling is Encounter. Words, emptied of precise denotation by an act of eternal (infernal) repetition, evoke other presences. The third moment seldom reached in the drama and only fleetingly reached in recent plays is the ritual moment of Reawakening. (1988, p.74)

This threefold function is remarkably comparable to what Arberry (2001) believes about the function of repetition in Sufism. Evaluating Rumi's basic elements of mystical trends, he argues that denial, intrusion and divine presence are the three parts of repetition. Within this context, Doll's notion of 'regression' is very similar to Arberry's definition of 'denial'. Encountering, in a similar vein, echoes what Arberry explains as intrusion and divine presence (27). In Endgame Hamm demonstrates such a regressive process where the conscious ego is cyclically denied.

After Hamm's continual regressive exercises, what is left for him is his blood-stained handkerchief which implies his complete self-renunciation and a mystic-like abolition of any desire which is also manifest in the image of closed eyes. His restful position indicates the complete inner will-less repose represents self-annihilation. As Hayman (1980) says: "One of the reasons for the frequent recurrence of blindness in Beckett's work is that it forces the victim to look inwards, and seeing nothing he may see Nothing" (40).

Cornwell (1973) maintains that "the Beckett hero attempts to reverse the process of birth and speed his return to the state of pre-conscious non-being from which he came; that is his lost Eden" (41). He refers to Hamm's taking painkiller as a way of deadening awareness and lessening the agony of consciousness. The Nothing which Hamm might see is the annihilation of the ego or the Non-existence which is mystically the prelude to the manifestation of the whole Being. Hamm's ability to see Nothing after seeing nothing reflects Beckett's belief in Bruno's mystic notion of the contraries which emphasize that "Maximal negation is minimal affirmation" (qtd. in Fletcher ,1965, p.126).

Hamm's static position at the end of the play which coincides with the announcement of playing again implies the simultaneous cancellation and commencement. In Sufism, likewise, the spiritual self-realization depends on penetrating beyond the exterior multiplicity of phenomena to a unified whole. Attaining this kind of self-unification, as Ibn al'Arabî (1980) believes, entails the abolition of the ego or passing away from self. What Ibn al- 'Arabî then calls "perpetual effusion" is actually the process of effusing the borrowed feature of being to reach the state on non-being that is the essence (I. 150). Such a mystical paradox is also manifest in Waiting for Godot and Happy Days where waiting and being buried, which represent passive non-being, ironically witness a meaningful being.

The final symbolic peace Winnie gains at the end of the play demonstrates the conscious burial of her sensual life. The outset of self-renunciation which starts through waiting in Godot continues by excessive exercises of ending in Endgame and finally culminates in the attainment of peace and the ultimate dissolution of the sensual self in Happy Days. The peaceful condition which is finally achieved at the end of conscious self-annihilation of the characters in Beckett's major plays is very similar to rapturous annihilation or the conscious perdition of the sensual life which leads to the manifestation of transcendental self in Sufism. In Divan e Shams, Rumi (2001) clearly refers to this kind of spiritual happiness which lies on cancellation of the sensual organ:

How joyous the time that I silence my voice

Spirit's voice my soul with joy inflate.

I shall pack my bags, leave this world for that

Witness the order that Thou will create. (90)

This recurrent motif is the manifestation of Beckett's mystic idea reflected in Three Dialogues. Here, the nearness of the two phrases of "the ultimate penury" and "al-Haqq" coming shortly one after another, as Gibson (2006) asserts, conveys the Sufi motif of self-renunciation: 
Beckett has argued for the importance of 'the ultimate penury,' as the state of being not merely 'short' of world and 'self,' but 'without these esteemed commodities'. Duthuit appears to hear this ascetic valuation of renunciation as close to the Sufi insistence on a discipline in which the 'wayfarer' loosens and, at length, altogether severs the worldly bonds of his lower self. It is this, more than anything else that is the immediate occasion for the reference to al-Haqq. (49)

He also postulates that Beckett was really influenced by Sufism through the French Sufi scholar Loui Massignon who was a major source for Western knowledge of Sufism via his Passion of Hallaj and his interest in the Sufi heresy of alHaqq. Gibson thus explains the Sufi moment of revelation (al-Haqq) where the questers can attain the authentic self after being purified enough to attain total renunciation. Trying to remain "empty and bare", it can be recognized that Beckett's dramatic characters are involved in a process of self- stripping actions which can be considered as the Sufi process of self-annihilation and self-realization. The idea is also reminiscent of mystic Eckhartian soul which prepares the ground for giving birth to spirituality (Almond, 2000, p.176). Such a paradoxical motif is once more reflected in Robinson's The Long Sonata of the Dead:

Beckett's nothing in fact designates a transcendent fullness opposed to the material world...... the nothing signifies an ultimate transcendence ......making Beckett into a Gnostic. All concur that Beckett is attempting an ascetic disengagement from temporal reality in the name of an essence beyond it. ... such that to attain essence is to be unable to express it. Language is accordingly considered a barrier between man and knowledge, since the truth beyond words is unreachable" beyond the web of words lies nothing: language does not express reality. All speech is lying. Truth is silent. (qtd. in Wolosky, 1995, p. 225)

Indeed, to complete the readings that unravel the transcendent moment of nothingness in Beckett's play, I should add that it is the continuous undoing of the characters which leads them to absence. Beckett's non-heroes thus verify that "the only way to 'have done' is not to be there in the sense of not being present in the normalized ego-state" (Davis, 2000, p. 401).

It can be finally recognized that the psychological theory of transmuting the ego to the spiritual world of unconscious in the twentieth century thought appears in the shape of quasi-mystic self-tantalizing actions of the absurd characters which transcend the conscious ego without destroying it. In line with such transmutation, the absurd dramatic characters are mysteriously impelled by the anarchy of language toward a Nirvana-like state of inner awareness. The final implied happiness of Becket's characters along with the explicit promise of peace and salvation remarkably demonstrate a comprehensive degree of success compared to the catastrophic fall of Renaissance tragic heroes or the transitory selfsuspension of nineteenth century-dramatic characters.

In the light of such a degree of success, the apparently negative quest of the absurd dramatic characters is approved to be ironically fruitful in nullifying the alluring ego and transmuting it to the spiritual world of unconscious. Although the conscious choice of the absurd dramatic characters in complete withdrawal from the ego makes them engage in a recurrent, cyclical self-nullification that is apparently a vicious, tragic project, such dramas reveal the positive nature of tragedy in leading "consciousness away from life to an alleged better consciousness, a will-less world" (Trigg, 2008, p. 176). In other words, although the continuous self-renunciation of Beckett's characters makes them recurrently lose the sense of everyday life and produce a tragic annihilating effect, the end result of such a reductive process is one of transcendence.

Unlike the number of criticisms already available concerning the characters' grappling with the problems of the self which deal in a scattered way with separate playwrights, this study demonstrates that as representatives of the absurd dramas, Beckett's plays reveal a similar self-annihilating strategy in the quest for an authentic self. Such an annihilating approach is uniquely interwoven with the psychological understanding of the present and can also be understood as part of a mystical tradition consistent with the Sufi notion of continuous loss and gain. Within this context, the overall pattern of self-reduction which includes the loss of mobility, sight, and speech is demonstrated to end in a complete self-renunciation that in turn reveals a comprehensive degree of self-realization.

\section{REFERENCES}

[1] Almond, Ian. (2000). “Absorbed into the Other: a Neoplatonic Reading of the Birthday Party.” Literature and Theology, 14 (2), 174-88.

[2] Al-Tirmadhi, A \& Al-Sulami. (2003). Three Early Sufi Texts. Trans. Nicholas Heer and Kenneth L. Honerkamp. Louisville: Fons Vitae.

[3] Arberry, A. J. (2001). Sufism; an account of the mystics on Islam. Mineola, NY: Dover Publications.

[4] Asmus, Walter. (1982). "Light, Sound, Movement and Action in Beckett's Rockaby." Modem Drama, 25 (3), 343-351.

[5] Beckett, Samuel. (1931). Proust. London: Grove Press.

[6] Buri, Fritz. (1997). The Buddha-Christ as the lord of the true self. Trans. Harold H. Oliver. Georgia: Mercer University Press.

[7] Coe, Richard. (1968). Beckett. London: Oliver \& Boyd.

[8] Cohn, R. (1962). Samuel Beckett: The Comic Game. New Brunswick: Rutgers University Press.

[9] Davis, Paul. (2000). "On Beckett's Metaphysics of Non-Location: Vagrancy, Void, and Formless Fire." Samuel Beckett Today, (9), 399-407.

[10] Doll, Mary. (1988). Beckett and Myth: An Archetypal Approach. Syracuse: Syracuse University Press.

[11] Federman, Raymond. (1979). Samuel Beckett: the Critical Heritage. London: Routledge and Kegan Paul.

[12] Fletcher, J. (1965). "Samuel Beckett and the Philosophers." Comparative Literature 17(1), 43-56. 
[13] Ghosh, Ranjan. (2004). "Reconfiguring the Waiting for Godot: Explorations Within Some Paradigms of Hindu Philosophy." Samuel Beckett Today/Aujourd'hui, 4, 307-21. (Rodopi Press: Amsterdam \& Atlanta).

[14] Heilpern, John. (1999). trans. Conference of Birds. Farid al-din Attar. London: Routledge.

[15] Ibn-e-Arabi, Muhyi al- Din. (1980). Fusus al-hikam (The Bezels of Wisdom). Trans. R.W.J. Austin, New York: Paulist Press.

[16] Kalb, Jonathan. (1989). Beckett in Performance. Cambridge: CUP.

[17] Kim, Catherine. (2003). "The Lacanian Subject as Breach/Fixation: A Contribution to the Social Theory of Psychoanalysis." Journal for Lacanian Studies, 1 (2), 261-277.

[18] Lamont, Rosette. C. (1957). "The Metaphysical Farce: Beckett and Ionesco.” The French Review, 1(46), 319-28.

[19] McDonald, Ronan. (2006). The Cambridge Introduction to Samuel Beckett. Cambridge: Cambridge University Press.

[20] Metman, Eva. (1960). "Reflections on Samuel Beckett's Plays." Journal of Analytical Psychology, 5(1), 41-63.

[21] Nott, Charles Stanley. (1954).Trans. The Conference of the Birds. By Farid Ud-Din-Attar. London: Routledge.

[22] Robbe-Grillet, Alain. (1963). For a new novel: essays on fiction. Illinois: North Western University Press.

[23] Rumi, Jalal al-Din. (2001). Divan-e Shams-e Tabriz. Trans. Reynold Alleyne Nicholson, California: The University of California.

[24] ---. Mathnawi. (1898). Trans. E.H. Whinfield, Oxford: Oxford University Press.

[25] Sartre, J. P. (1953). Being and Nothingness: An Essay on Phenomenological Ontology. New York: Harvard University Press.

[26] Soroush, Ambdolkarim. (2000). Amorous Gamble. Tehran: Serat.

[27] Trigg, Dylan. (2008). "Schopenhauer and the Sublime Pleasure of Tragedy." Philosophy and Literature, 28 (1), $165-179$.

Bahee Hadaegh, Born in Shiraz/Iran, 08.01.1974. Ph.D. english literature, drama (NSW, Austraila, Wollongong University, 2009). M.A. english literature (Shiraz, Iran, Shiraz State University, 2000). B.A. English Literature( Kerman, Iran, Kerman State University, 1998).

She is presently working as Assistant Professor at department of English Literature, Shiraz State University, Shiraz, Iran. She is a full-time faculty member teaching Literature courses to M.A. and B.A. students. She is also thesis examiner of Ph.D. candidates. She has 8 years of teaching experience at different universities in addition to part-time jobs at IELTS centre in Australia. More than four years of constant cooperation with Translation offices, translating literary, philosophical, technical, and medical texts.

Her recently published book (Towards Ennobling Absence, Saarbrücken, Germany, Lambert Academic Publication, August 24, 2012) is an inclusive study of the development of Western Tragedy which surprisingly shows the influence of Persian Mysticism on Modern plays. She has also published papers in Kata, and Epiphany. Her specialty is Drama and Comparative Studies focusing on Eastern Mysticism and Western Literature. Her idea about the effective applicability of literature in moral enhancement of societies is what supports the majority of her researches. 